\title{
HSCT with Mismatched Unrelated Donors (MMUD): A Comparison of Different Platforms for GvHD Prophylaxis
}

\author{
Massimo Berger 1,*(D), Marta Barone ${ }^{1}\left(\mathbb{D}\right.$, Fabrizio Carnevale-Schianca ${ }^{2}$, Marco De Gobbi ${ }^{3}$, Paolo Nicoli ${ }^{3}$, \\ Daniela Caravelli $^{2}$, Daniela Cilloni ${ }^{3}$ (D), Luca Paruzzo ${ }^{2}$, Manuela Spadea ${ }^{1}$, , Katia Mareschi 1,4 (D), \\ Massimo Aglietta ${ }^{2}$ and Franca Fagioli ${ }^{1,4}$
}

check for updates

Citation: Berger, M.; Barone, M.; Carnevale-Schianca, F.; De Gobbi, M.; Nicoli, P.; Caravelli, D.; Cilloni, D.;

Paruzzo, L.; Spadea, M.; Mareschi, K.; et al. HSCT with Mismatched Unrelated Donors (MMUD): A Comparison of Different Platforms for GvHD Prophylaxis.

Transplantology 2022, 3, 51-67.

https: / /doi.org/10.3390/

transplantology3010006

Academic Editors: Anca Colita,

Alina Tanase and Ciprian Tomuleasa

Received: 16 November 2021

Accepted: 27 January 2022

Published: 8 February 2022

Publisher's Note: MDPI stays neutral with regard to jurisdictional claims in published maps and institutional affiliations.

Copyright: (C) 2022 by the authors. Licensee MDPI, Basel, Switzerland. This article is an open access article distributed under the terms and conditions of the Creative Commons Attribution (CC BY) license (https:// creativecommons.org/licenses/by/ $4.0 /)$.
1 Pediatric Onco-Hematology, Turin Metropolitan Transplant Center, Regina Margherita Children Hospital, City of Health and Science, University of Turin, Piazza Polonia 94, 10126 Turin, Italy; marta.barone@edu.unito.it (M.B.); manuela.spadea@gmail.com (M.S.); katia.mareschi@unito.it (K.M.); franca.fagioli@unito.it (F.F.)

2 Medical Oncology, Turin Metropolitan Transplant Center, Candiolo Cancer Institute, FPO-IRCCS, University of Turin, 10060 Candiolo, Italy; fabrizio.carnevale@ircc.it (F.C.-S.); daniela.caravelli@ircc.it (D.C.); luca.paruzzo@ircc.it (L.P.); massimo.aglietta@ircc.it (M.A.)

3 Dipartimento di Scienze Cliniche e Biologiche, Turin Metropolitan Transplant Center, AOU San Luigi Gonzaga, University of Turin, 10043 Orbassano, Italy; marco.degobbi@unito.it (M.D.G.); p.nicoli@sanluigi.piemonte.it (P.N.); daniela.cilloni@unito.it (D.C.)

4 Department of Public Health and Pediatrics, University of Turin, 10126 Torino, Italy

* Correspondence: mberge@cittadellasalute.to.it or massimoberger@gmail.com; Tel.: +39-0113135449; Fax: +39-0113135375

\begin{abstract}
HSCT from an unrelated HLA-mismatched donor (MMUD) is one of the alternatives where an HLA-matched donor is not found. The aim of this study was to compare GvHD prophylaxis with anti-thymocyte globulin (ATG) vs. post-transplant cyclophosphamide (PT-Cy). Thirty-nine adult patients were uniformly treated with rabbit ATG-Cy-A-MTX and peripheral blood stem cell (PBSC) and 40 adult patients with PT-Cy-MMF-tacrolimus and PBSC. This retrospective study was registered at ClinicalTrials.gov NCT04598789. Three-year overall survival was $42 \%$ vs. $64 \%$ for ATG and PT-Cy $(p<0.0005)$, three-year treatment-related mortality (TRM) was 36\% vs. 8\% $(p=0.0033)$ and the three-year relapse incidence (RI) was $15 \%$ vs. $28 \%(p=\mathrm{NS})$, respectively. The incidences of day-100 GvHD graded II-IV and III-IV were 39\% vs. $7 \%(p=0.0006)$ and $11 \%$ vs. $0 \%(p=0.04)$, respectively, whereas the three-year cGvHD incidences were $48 \%$ vs. $13 \%$ ( $p=0.0005)$, respectively. We were able to show how PT-Cy can reduce the incidence of GvHDs and TRM in adults, but relapse remains an issue.
\end{abstract}

Keywords: mismatched unrelated donor; anti-thymocyte globulins; post-transplant cyclophosphamide

\section{Introduction}

Hematopoietic stem cell transplantation (HSCT) remains the only curative option for many patients with hematologic malignancies. The best donor for HSCT is an identical human leukocyte antigen (HLA) graft from a matched related donor (MRD) or matched unrelated donor (MUD). Unfortunately, based on average family size, less than $30 \%$ of patients will have an MRD [1] and strategies to identify alternative stem cell sources in the absence of a MUD are needed. Currently, a commonly used strategy is to find a mismatched unrelated donor (MMUD), a haploidentical donor or an umbilical cord blood unit [2]. The main concern with MMUD transplant remains incidences of graft-versus-host disease (GvHD). The estimated risk of acute GvHD in MMUD transplant has varied greatly across studies, with cumulative incidences from 13 to 80\% [3-6]. However, the HLA disparity, which has been associated with GvHD, also presents some beneficial effects allowing a more sustained graft-versus-tumor effect, which is thought to be part of the mechanism for preventing disease relapse after HSCT. A large registry study of almost 4000 patients 
reported increased mortality for an allele or antigen single mismatch (7/8) at HLA-A, -B, -C or -DRB1 compared with $8 / 8$ MUD transplantation. A second analysis examined allele and antigen mismatches separately with no increase in mortality for single allele mismatches compared to MUD transplantation [7,8]. Rabbit anti-thymocyte or anti-lymphocyte globulins (ATG/ALG) are now frequently used for GvHD prevention in Europe [9,10], with the highest percentage of evidence derived from randomized clinical trials (RCTs), non-RCTs, and meta-analyses. ATG/ALG effectively prevents GvHD, in particular chronic GvHD (cGvHD), following transplant from almost any donor type [11-14].

Post-transplant high dose cyclophosphamide (PT-Cy) alone has been evaluated primarily after bone marrow transplant and found to be safe and effective [15-18]. The role of PT-Cy in MMUD can potentially overcome the negative impact of HLA disparity, as in haploidentical transplants [19-21]. Recently, by using the registry data from the Acute Leukemia Working Party of the European Society for Blood and Marrow Transplantation, two papers compared PT-Cy and ATG. Battipaglia et al. performed a matched-pair analysis on 272 patients (179 vs. 93) comparing those two strategies in a 9/10 MMUD setting in adults. A significantly lower incidence of severe acute GvHD with PT-Cy compared with ATG together with higher leukemia-free survival (LFS) and GvHD/relapse-free survival (GRFS) [22] was observed. Nagler et al. showed comparable data for PT-Cy and ATG in the haploidentical setting for ALL in adults. Using multivariate analysis (MVA), the LFS and OS were found to be higher with PT-Cy compared to ATG prophylaxis, while the RI was lower in the PT-Cy group $(p=0.03)$ and TRM was not different [23].

The aim of this study was to retrospectively compare survival rates and GvHD incidence in two cohorts of adult patients transplanted with PBSC and treated with different GVHD prophylaxis: ATG-Methotrexate (MTX) and Cyclosporin-A (Cy-A)- or PT-CyMofetil mycophenolate (MMF) and tacrolimus [24-26].

The strength of this study is represented by the common donor selection strategy, by common anti-infectious prophylaxis and SOS strategies and by the continuous discussion of cases both in the pre-transplant period and in the subsequent one.

\section{Patients and Methods}

We retrospectively analyzed data of MMUD HSCT outcomes at our adult centers, which include the Institute for Cancer Research and Treatment in Candiolo and Azienda Ospedaliera, Universitaria Ospedale San Luigi, Orbassano, Turin. The HSCTs were performed between 2011 and 2019. The policy of infection and SOS prophylaxis together with donor selection followed the same algorithms.

In brief, the infection policy was based on: (a) antifungal prophylaxis with fluconazole for all patients except those who had already developed a fungal infection for whom secondary prophylaxis was based on posaconazole or voriconazole, (b) antiviral prophylaxis was given with acyclovir from day -1, and (c) SOS prophylaxis was based on the administration of ursodeoxycholic acid at a dose of $10 \mathrm{mg} / \mathrm{kg}$ after performing a hepatic fibro-scan before HSCT in order to monitor the presence of hepatic fibrosis. During hospitalization all patients were weighed twice a day and their abdominal circumference measured once a day, while liver enzymes were monitored daily. In the case of any variation of these parameters, the policy was reduction of fluids, administration of diuretics and albumin and administration of defibrotide at a dose of $6.25 \mathrm{mg} / \mathrm{kg}$ four times a day for at least 21 days. The donor selection was based on the following criteria: (1) HLA compatibility being first (a) HLA-DRB1 match, (b) HLA-B match, (c) HLA-A match, (d) HLA-C match, (e) HLA-DQB1 match; (2) selection based on the gender of the donor being first (a) male, (b) female without pregnancy, (c) female with previous pregnancies; (3) blood group being first (a) AB0 matched, (b) minor incompatibility, (c) major incompatibility. Regarding GvHD prophylaxis, one center adopted prophylaxis with ATG-Cy-A and MTX, whereas the other used PT-CY-tacrolimus and Mycophenolate. Therefore, it is important to specify that the distribution of patient/donor/transplant variables will therefore be random. 
The search for the unrelated donor was performed by the coordinator center located at the Regina Margherita Children's Hospital. Table 1 describes the main clinical characteristics of the study population. All patients underwent their first allogeneic HSCT and there were evidently significant differences at the baseline between the groups: (1) the patients' age was more advanced in the ATG group, (2) an intermediate to high disease risk index (DRI) $[27,28]$ was more present in the ATG group, (3) the interval between diagnosis and HSCT was greater in the PT-Cy group, (4) TBI was mostly chosen in the ATG group, and (5) a reduced intensity regimen (RIC) was more frequently chosen in the ATG group. The European Blood and Marrow Transplant (EBMT) [29] scores did not differ among the groups. A total of 10 patients underwent HSCT after an RIC, where the majority were in the ATG group (8 out of 10). The study was approved by the Institutional Review Board $\mathrm{N}^{\circ}$ 00266/2019 and it was registered at ClinicalTrials.gov NCT04598789. All patients or their legal guardians signed the appropriate consent form at the time of HSCT for recording data and clinical outcomes. All authors had access to primary clinical trial data.

Table 1. Characterization of patients and donors in studied transplants. Demographics of patientdonor-transplants. $\mathrm{CSA}=$ cyclosporine-A, MTX = methotrexate, $\mathrm{ATG}=$ anti-thymocyte globulin, $\mathrm{MMF}=$ Mofetil mycophenolate, $\mathrm{PT}-\mathrm{Cy}=$ post-transplant Cyclophosphamide, ALL $=$ acute lymphoblastic leukemia, $\mathrm{AML}=$ acute myeloid leukemia, $\mathrm{CLL}=$ chronic lymphocytic leukemia, $\mathrm{CML}=$ chronic myeloid leukemia, $\mathrm{MDS}=$ myelodysplastic syndrome, $\mathrm{MM}=$ multiple myeloma, $\mathrm{NHL}=$ non-Hodgkin lymphoma, $\mathrm{HD}=$ Hodgkin lymphoma, $\mathrm{TBI}=$ total body irradiation, $\mathrm{RIC}=$ reduced intensity conditioning, $\mathrm{MAC}=$ myeloablative conditioning, $\mathrm{MM}=$ mismatch MF $=$ Mielofibrosis

\begin{tabular}{|c|c|c|c|c|}
\hline & & $\begin{array}{c}\text { CSA+MTX+ATG } \\
\mathbf{N}=39\end{array}$ & $\begin{array}{c}\text { Tacrolimus+MMF+PTCy } \\
\text { N }=40\end{array}$ & $p$ \\
\hline \multirow[t]{2}{*}{ Patient gender } & Male & $24(61 \%)$ & $25(62 \%)$ & NS \\
\hline & Female & $15(38 \%)$ & $15(37 \%)$ & \\
\hline \multirow[t]{2}{*}{ Patient age } & $\geq 60$ & $17(43 \%)$ & $8(20 \%)$ & 0.02 \\
\hline & $<60$ & $22(56 \%)$ & $32(80 \%)$ & \\
\hline \multirow[t]{9}{*}{ Disease } & ALL & $8(20 \%)$ & $6(15 \%)$ & NS \\
\hline & AML & $19(49 \%)$ & $18(45 \%)$ & \\
\hline & CLL & $2(5 \%)$ & $1(2 \%)$ & \\
\hline & CML & $1(2 \%)$ & 0 & \\
\hline & MDS & $5(13 \%)$ & $2(5 \%)$ & \\
\hline & MM & $2(5 \%)$ & $7(17 \%)$ & \\
\hline & NHL & $1(2 \%)$ & $2(5 \%)$ & \\
\hline & $\mathrm{HL}$ & 0 & $3(7 \%)$ & \\
\hline & MF & $1(2 \%)$ & $1(2 \%)$ & \\
\hline \multirow[t]{4}{*}{ Disease risk index } & Low & $3(8 \%)$ & $9(22 \%)$ & 0.04 \\
\hline & Intermediate & $26(67 \%)$ & $16(40 \%)$ & \\
\hline & High & $10(25 \%)$ & $15(37 \%)$ & \\
\hline & Very high & 0 & 0 & \\
\hline \multirow[t]{4}{*}{ EBMT score } & 2 & 0 & $3(7 \%)$ & NS \\
\hline & 3 & $8(20 \%)$ & $6(15 \%)$ & \\
\hline & 4 & $8(20 \%)$ & $12(30 \%)$ & \\
\hline & 5 & $16(41 \%)$ & $7(17 \%)$ & \\
\hline
\end{tabular}


Table 1. Cont.

\begin{tabular}{|c|c|c|c|c|}
\hline & & $\begin{array}{c}\mathrm{CSA}+\mathrm{MTX}+\mathrm{ATG} \\
\mathbf{N}=39\end{array}$ & $\begin{array}{c}\text { Tacrolimus+MMF+PTCy } \\
\qquad N=40\end{array}$ & $p$ \\
\hline & 6 & $6(15 \%)$ & $12(30 \%)$ & \\
\hline & 7 & $1(2 \%)$ & 0 & \\
\hline \multirow[t]{2}{*}{$\begin{array}{c}\text { Interval } \\
\text { diagnosis-HSCT }\end{array}$} & $>1$ year & $17(43 \%)$ & $27(67 \%)$ & 0.04 \\
\hline & $<1$ year & $22(56 \%)$ & $13(32 \%)$ & \\
\hline \multirow[t]{2}{*}{ Conditioning } & TBI-based & $9(23 \%)$ & $2(5 \%)$ & 0.02 \\
\hline & $\begin{array}{l}\text { Chemo- } \\
\text { based }\end{array}$ & $30(77 \%)$ & $38(95 \%)$ & \\
\hline \multirow[t]{2}{*}{$\begin{array}{l}\text { Intensity of } \\
\text { conditioning }\end{array}$} & RIC & $8(20 \%)$ & $2(5 \%)$ & 0.04 \\
\hline & MAC & $31(80 \%)$ & $38(95 \%)$ & \\
\hline \multirow[t]{2}{*}{ Donor gender } & Male & $23(59 \%)$ & $27(\%)$ & \\
\hline & Female & $16(41 \%)$ & $13(67 \%)$ & \\
\hline \multirow[t]{2}{*}{ Donor age } & $>30$ & $15(38 \%)$ & $20(50 \%)$ & NS \\
\hline & $<30$ & $24(61 \%)$ & $20(50 \%)$ & \\
\hline \multirow[t]{2}{*}{ Gender relation } & $\mathrm{F}>\mathrm{M}$ & $16(41 \%)$ & $16(40 \%)$ & NS \\
\hline & other & $23(59 \%)$ & $24(60 \%)$ & \\
\hline \multirow[t]{2}{*}{ PBSC CD34+ cells } & $>$ median & $19(49 \%)$ & $18(45 \%)$ & NS \\
\hline & $<$ median & $20(51 \%)$ & $22(55 \%)$ & \\
\hline HLA-A mismatch & & $18(46 \%)$ & $23(57 \%)$ & NS \\
\hline HLA-B mismatch & & $8(20 \%)$ & $6(15 \%)$ & \\
\hline HLA-C mismatch & & $12(31 \%)$ & $9(22 \%)$ & \\
\hline $\begin{array}{l}\text { HLA-DQB1 } \\
\text { mismatch }\end{array}$ & & $8(20 \%)$ & $10(25 \%)$ & \\
\hline $\begin{array}{c}\text { Double class } 1 \\
\text { mismatch }\end{array}$ & & $3(7 \%)$ & $2(5 \%)$ & \\
\hline $\begin{array}{l}\text { Double class I and } \\
\text { class II mismatch }\end{array}$ & & $4(10 \%)$ & $6(15 \%)$ & \\
\hline
\end{tabular}

\subsection{HLA Typing}

HLA-typing was performed at the Immunogenetica and Biologia dei Trapianti, University of Turin. The donor-patient couples were DNA typed by high resolution polymerase chain reaction (PCR) at the HLA-A, B, C, DRB1 and DQB1 loci [30-32]. The HLA mismatch was defined as the difference between donor and recipient (including allele or antigen mismatch) in the GVH (including all-bidirectional mismatch) and HVG. In the case of the co-presence of double mismatches involving both $\mathrm{GvH}$ and host-versus-graft $(\mathrm{HvG})$ vectors at different loci (for instance HLA-A and HLA-DQB1), the patients were arbitrarily assigned to the $\mathrm{GvH}$ group. No data for permissive nor non-permissive mismatches were reported $[33,34]$.

\subsection{Engraftment and GvHD Prophylaxis}

Absolute neutrophil count (ANC) engraftment was defined as the first of three consecutive days of ANC above $0.5 \times 10^{9} / \mathrm{L}$, independently of G-CSF administration. Platelet engraftment was defined as the first of three consecutive days of unsupported platelet counts above $50 \times 10^{9} / \mathrm{L}$. Acute and chronic GvHD were classified according to Seattle criteria $[35,36]$. For the ATG group, GvHD prophylaxis consisted of rabbit anti-thymocyte 
globulins (ATG, Thymoglobulin, Genzyme Europe B.V. Paasheuvelweg 251105 BP Amsterdam, The Netherlands) at $2.5 \mathrm{mg} / \mathrm{kg} /$ day from day -4 to day -2 (total dose $7.5 \mathrm{mg} / \mathrm{kg}$ ) combined with Cy-A from day -1 at $3 \mathrm{mg} / \mathrm{kg}$ iv up to engraftment and then $5-8 \mathrm{mg} / \mathrm{kg}$ orally to maintain blood concentration between 100 to $250 \mathrm{ng} / \mathrm{mL}$. The Cy-A was given for 4-6 months according to the patients' underlying disease status and GvHD development. MTX was given at $10 \mathrm{mg} / \mathrm{m}^{2}$ on day +1 and then at $8 \mathrm{mg} / \mathrm{m}^{2}$ on days $+3,+6$ and +11 . In this patient group, the goal was to discontinue immunosuppression at day +120 in the absence of immune-mediated complications or incipient relapse of the underlying disease.

For the PT-Cy group, the GvHD prophylaxis consisted of high dose cyclophosphamide at $50 \mathrm{mg} / \mathrm{kg} /$ day on days +3 and +4 together with tacrolimus at $0.06 \mathrm{mg} / \mathrm{kg}$ twice daily to maintain blood concentration in the range of $5-15 \mathrm{ng} / \mathrm{mL}$ by day +5 to day +81 when a taper was started. MMF was administered orally by day +5 to day +28 at $15 \mathrm{mg} / \mathrm{kg}$ three times per day. In this patient group, the goal was to discontinue immunosuppression at day +90 in the absence of immune-mediated complications or incipient relapse of the underlying disease. A total of 10 patients received a reduced intensity conditioning (13\%), and the remaining 69 patients underwent HSCT following a myeloablative conditioning $(87 \%)$ [37]. Fractionated total body irradiation was administered over three days in six factions (total dose 12 Grays). None of the patients received any type of maintenance after HSCT.

\subsection{Statistical Analysis}

The primary endpoint of the study was day 100 acute GvHD II-IV incidence, with secondary endpoints being: day 100 acute GvHD III-IV, three-year chronic GvHD incidence, three-year overall survival (OS), three-year transplant-related mortality (TRM) incidence, three-year relapse incidence (RI) and neutrophil and platelets engraftment.

Categorical variables related to patients, disease, and transplant procedure were compared using the chi-squared or Fisher's exact test (VassarStats: Statistical Computation Web Site) and quantitative variables with the Mann-Whitney test (Mann-Whitney U Test Calculator (socscistatistics.com)). In the case of several nonparametric groups, the KruskallWallis test was used (Conover (1999), "Practical Nonparametric Statistics," Second Edition, Wiley, pp. 288-297 [38], Walpole and Myers (2012), "Probability and Statistics for Engineers and Scientists," Ninth Edition, Pearson [39]). OS was defined as the probability of survival irrespective of the state of the disease. This was calculated as the interval between the HSCT date and the last follow-up or death, whichever occurred first. Graft failure (GF) patients were censored only for the GvHD cumulative incidence analysis. GF was defined as either lack of initial engraftment of donor cells (primary graft failure), loss of donor cells after initial engraftment (secondary graft failure) or simply the failure to reach ANC above $0.5 \times 109 / \mathrm{L}$ or platelets above $50 \times 109 / \mathrm{L}$.

TRM was defined as the probability of dying without recurrence of the underlying disease. Relapse was defined as the reappearance of tumor cells at any site. To assess and compare the transplant risk of these populations we measured the DRI and EBMT risk scores for all the patients [27-29].

Acute GVHD II-IV, acute GVHD III-IV and chronic GVHD cumulative incidences were calculated using NCSS software. The competing risks for GvHDs were relapse and death in remission. OS was calculated by Kaplan-Meier statistics [40] and the log-rank test was used to calculate $p$ values [41]. Relapse was considered the competing event to calculate TRM, while TRM was the competing event for calculating RI. The RI cumulative curves were calculated with NCSS software, while the statistical differences were calculated with the Gray test [42] using the R package (https:/ / www.r-project.org/). In the analysis any type of relapse (hematological or involving any extra site) was considered as an event. All variables having a $p$ value below 0.20 in univariate analyses were included in a multivariate analysis using the Cox regression model, and the proportional sub-distribution hazard regression model was used to perform multivariate analyses of RI and TRM. Statistical analysis was performed using computer software (SPSS, SPSS, Inc., Chicago, IL, USA) to 
calculate OS, while the cumulative incidence curves (TRM, RI and GvHDs) were calculated using another computer program (NCSS for Windows, NCSS, LLC, Kaysville, UT, USA). The $p$ values for both univariate and multivariate analyses were computed with a statistical computing program (R packages software, http:/ / www.rproject.org/). For all analyses, the significant $p$ value was 0.05 .

\section{Results}

The median follow-up was 14.9 months (0.3-85.4).

\subsection{Disease Risk Index and EBMT Risk Score}

To compare the groups, we calculated the DRI and the EBMT risk score. In the ATG group we had 3 patients at low risk (8\%), 26 at intermediate risk (67\%) and 10 at high risk (25\%). In the PT-Cy group we had 9 patients at low risk $(22 \%), 16$ patients at intermediate risk $(40 \%)$ and 15 patients at high risk $(37 \%)(p=0.04)$. As illustrated in Table 1 , according to the EBMT risk score, no significant differences were found among the groups.

\subsection{HLA Typing}

A total of 41 couples were HLA-A mismatched (52\%), 14 were mismatched at the HLA-B locus (18\%), 21 at the HLA-C locus (26\%) and 18 at the DQB1 locus (23\%). According to our center's policy, no patients were mismatched at the HLA-DRB1 locus. Five patients had a double mismatch at HLA-class I (6\%) and 10 patients had a double mismatch at HLA class I and DQB1 (13\%).

\subsection{Neutrophils and Platelet Engraftment}

The neutrophils engraftment for the ATG and PT-Cy groups was achieved on days $+15(10-21)$ and $+14(12-23)(p=$ NS), respectively. The platelets engraftment was achieved on days $+21(13-41)$ and $+15(12-60)$, respectively $(p=N S)$. A total of five patients did not achieve neutrophils engraftment in the ATG group (13\%) and one patient in the PT-Cy group $(2 \%, p=\mathrm{NS})$. A total of nine patients did not achieve platelet above $50 \times 109 / \mathrm{L}$ in the ATG group (23\%) and one patient in the PT-Cy group $(2 \%, p=0.006)$. The kinetics of ANC and PLT engraftment are outlined in Figure $1 a, b$.

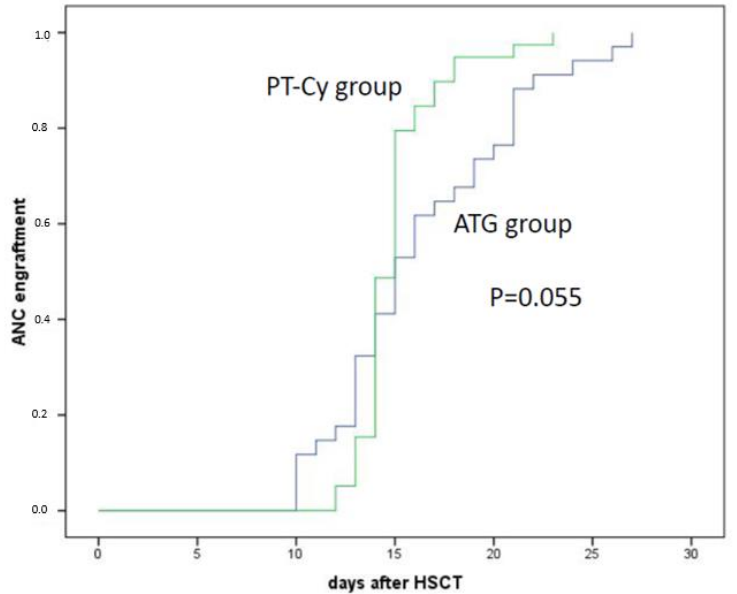

(a)

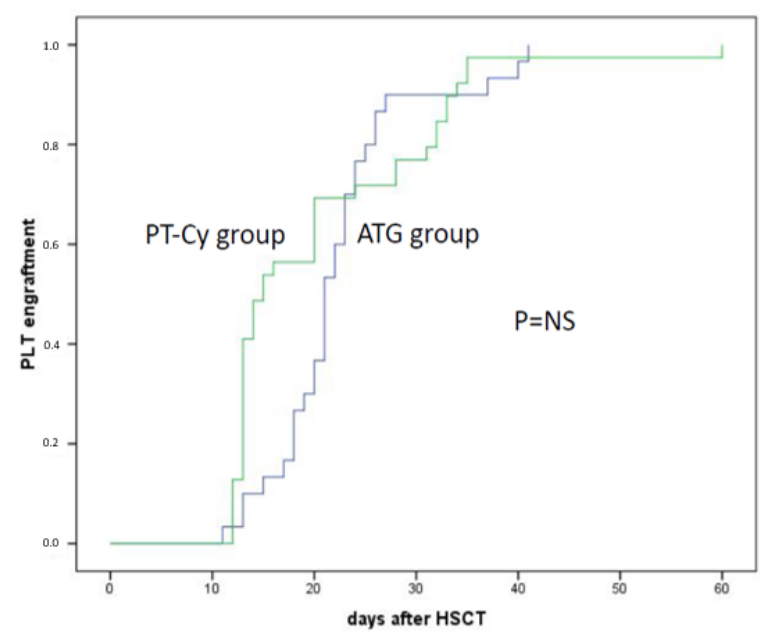

(b)

Figure 1. Neutrophil and platelet engraftment of patients treated with ATG (blue line) and with PT-Cy (green line). (a) Absolute neutrophil engraftment after mismatched unrelated donor transplantation $(p=0.055)$; (b) platelets engraftment after mismatched unrelated donor transplantation.

\subsection{Acute GvHD}

Among the entire population we had: 52 patients with no GvHD (66\%), 12 with GvHD graded I (15\%), 8 with GvHD graded II (10\%), 4 with GvHD graded III (5\%) and no patients 
with GvHD graded IV ( $0 \%)$. We were unable to evaluate three patients due to premature death; however, these cases were calculated for outcome as a competing event.

The overall day 100 GvHD II-IV and GvHD III-IV incidences were respectively $24 \%$ (95\% CI 18-33) and 6\% (95\% CI 1-24). Figure 2 shows GvHD II-IV and III-IV for the ATG and PT-Cy groups. In brief, the incidences of day $100 \mathrm{GvHD}$ graded II-IV and IIIIV were $39 \%$ vs. $7 \%(p=0.0006)$ and $11 \%$ vs. $0 \%(p=0.04)$ for the ATG and the PT-Cy groups, respectively.

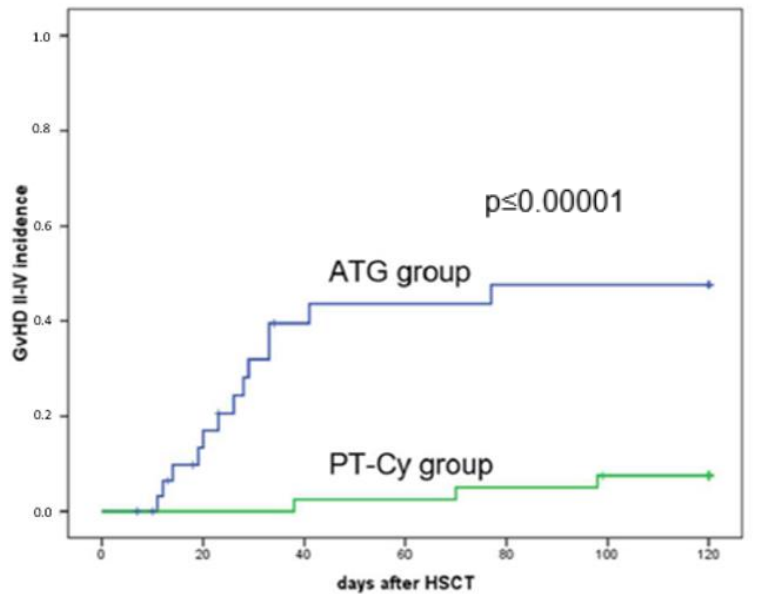

(a)

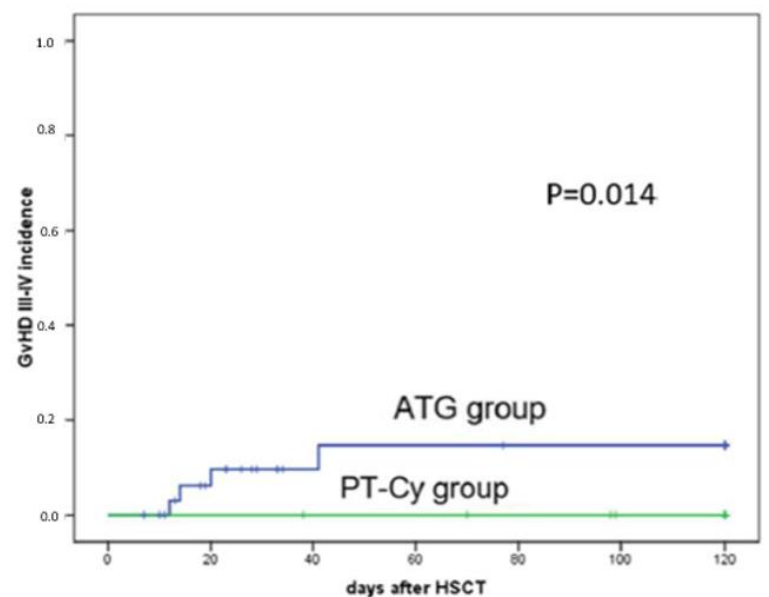

(b)

Figure 2. GvHD incidence of day 100 in patients treated with ATG (blue line) and PT-Cy (green line). (a) Acute GvHD II-IV incidence after mismatched unrelated donor transplantation was 39\% for the ATG group and 7\% for the PT-Cy group ( $p=0.0006)$; (b) acute GvHD III-IV incidence after mismatched unrelated donor transplantation was $11 \%$ for ATG and $0 \%$ for PT-Cy $(p=0.014)$.

As reported in Table 2 the univariate analysis showed how the conditioning regimen with TBI $(p=0.01)$, the GvHD prophylaxis with ATG $(p=0.0006)$ and the intensity of conditioning $(p=0.008)$ were significantly associated with a higher risk of GvHD II-IV. The multivariate analysis highlights that intensity of conditioning (OR 6.404, $p=0.008)$ and the GvHD prophylaxis with ATG (OR 1.28, $p=0.05$ ) were independent risk factors for GvHD II-IV. Younger patient's age was a protective factor (OR 0.210, $p=0.028$ ) (Table 3).

Table 2. (a) Analysis of day-100 GvHDs following mismatched HSCT; (b) analysis of OS, TRM, RI following mismatched HSCT. Univariate analysis for outcomes. $\mathrm{M}=$ male, $\mathrm{F}=$ female, ATG = anti-thymocyte globulin, PT-Cy = post-transplant cyclophosphamide, TBI = total body irradiation, RIC = reduced intensity conditioning, MAC = myeloablative conditioning, DRI = disease risk index, $\mathrm{MM}=$ mismatch, $\mathrm{OS}=$ overall survival, $\mathrm{TRM}=$ transplant-related mortality, $\mathrm{RI}=$ relapse incidence .

(a)

\begin{tabular}{|c|c|c|c|c|c|c|c|}
\hline & & $\begin{array}{c}\text { DAY-100 } \\
\text { aGvHD II-IV } \\
(95 \% \text { CI })\end{array}$ & $p$ & $\begin{array}{c}\text { DAY-100 } \\
\text { aGvHD III-IV } \\
(95 \% \text { CI })\end{array}$ & $p$ & $\begin{array}{c}\text { 3-y cGvHD } \\
(95 \% \text { CI })\end{array}$ & $p$ \\
\hline \multirow[t]{2}{*}{$\begin{array}{l}\text { Patient's } \\
\text { gender }\end{array}$} & $\mathrm{M}$ & $22 \%(12-38)$ & NS & $8 \%(3-22)$ & 0.14 & $37 \%(25-55)$ & 0.04 \\
\hline & $\mathrm{F}$ & $22 \%(11-45)$ & & $0 \%$ & & $12 \%(4-36)$ & \\
\hline
\end{tabular}


Table 2. Cont.

\begin{tabular}{|c|c|c|c|c|c|c|c|}
\hline \multicolumn{8}{|c|}{ (a) } \\
\hline & & $\begin{array}{c}\text { DAY-100 } \\
\text { aGvHD II-IV } \\
(95 \% \text { CI })\end{array}$ & $p$ & $\begin{array}{c}\text { DAY-100 } \\
\text { aGvHD III-IV } \\
(95 \% \text { CI })\end{array}$ & $p$ & $\begin{array}{c}\text { 3-y cGvHD } \\
(95 \% \text { CI })\end{array}$ & $p$ \\
\hline \multirow[t]{2}{*}{ Patient's age } & $>60$ year & $18 \%(7-44)$ & NS & $0 \%$ & 0.17 & $28 \%(13-58)$ & NS \\
\hline & $<60$ year & $23 \%(14-38)$ & & $8 \%(3-20)$ & & $28 \%(18-44)$ & \\
\hline \multirow[t]{2}{*}{ Donor } & $\mathrm{M}$ & $18 \%(9-33)$ & NS & $4 \%(1-16)$ & NS & $24 \%(14-42)$ & NS \\
\hline & $\mathrm{F}$ & $30 \%(16-53)$ & & $7 \%(2-28)$ & & $32 \%(18-57)$ & \\
\hline \multirow[t]{2}{*}{$\begin{array}{c}\text { GvHD } \\
\text { prophylaxis }\end{array}$} & ATG-based & $39 \%(26-60)$ & 0.0006 & $11 \%(4-28)$ & 0.014 & $48 \%(33-70)$ & 0.0005 \\
\hline & PTCy-based & $7 \%(2-22)$ & & $0 \%$ & & $13 \%(6-30)$ & \\
\hline \multirow[t]{2}{*}{ Donor's age } & $>30$ & $13 \%(5-32)$ & 0.06 & $0 \%$ & 0.054 & $20 \%(10-41)$ & 0.09 \\
\hline & $<30$ & $28 \%(18-46)$ & & $9 \%(4-24)$ & & $35 \%(23-54)$ & \\
\hline \multirow[t]{2}{*}{$\begin{array}{l}\text { Gender } \\
\text { relation }\end{array}$} & $\mathrm{F}>\mathrm{M}$ & $21 \%(10-42)$ & NS & $6 \%(2-25)$ & NS & $27 \%(14-51)$ & NS \\
\hline & other & $23 \%(13-39)$ & & $4 \%(1-17)$ & & $29 \%(18-47)$ & \\
\hline \multirow[t]{2}{*}{ Conditioning } & TBI & $50 \%(27-93)$ & 0.01 & $9 \%(1-59)$ & NS & $22 \%(6-75)$ & NS \\
\hline & Chemo & $17 \%(10-30)$ & & $5 \%(1-14)$ & & $29 \%(20-44)$ & \\
\hline \multirow[t]{2}{*}{$\begin{array}{c}\text { Intensity of } \\
\text { conditioning }\end{array}$} & RIC & $52 \%(16-80)$ & 0.008 & $10 \%(0-28)$ & NS & $60 \%(30-90)$ & 0.007 \\
\hline & MAC & $17 \%(8-26)$ & & $5 \%(0-10)$ & & $28 \%(13-43)$ & \\
\hline \multirow[t]{3}{*}{ DRI } & low & $17 \%(5-59)$ & NS & $8 \%(1-54)$ & NS & $25 \%(9-67)$ & NS \\
\hline & intermediate & $22 \%(13-40)$ & & $5 \%(1-19)$ & & $30 \%(18-49)$ & \\
\hline & high & $24 \%(11-51)$ & & $4 \%(1-28)$ & & $28 \%(13-58)$ & \\
\hline \multirow[t]{6}{*}{ EBMT score } & 2 & $0 \%$ & & $0 \%$ & & $33 \%(7-100)$ & \\
\hline & 3 & $36 \%(17-72)$ & & $14 \%(4-51)$ & & $43 \%(23-78)$ & \\
\hline & 4 & $15 \%(5-42)$ & & $5 \%(1-34)$ & & $20 \%(8-48)$ & \\
\hline & 5 & $22 \%(9-53)$ & & $0 \%$ & & $21 \%(8-58)$ & \\
\hline & 6 & $23 \%(10-55)$ & & $6 \%(1-37)$ & & $31 \%(14-69)$ & \\
\hline & 7 & $0 \%$ & & $0 \%$ & & $100 \%$ & \\
\hline \multirow[t]{2}{*}{ HLA-A } & mismatch & $24 \%(13-42)$ & NS & $5 \%(1-20)$ & NS & $31 \%(18-52)$ & NS \\
\hline & match & $20 \%(10-39)$ & & $5 \%(1-21)$ & & $27 \%(16-48)$ & \\
\hline \multirow[t]{2}{*}{ HLA-B } & mismatch & $38 \%$ (19-76) & NS & $14 \%(4-51)$ & 0.05 & $46 \%(26-83)$ & 0.0003 \\
\hline & match & $18 \%(11-31)$ & & $3 \%(1-13)$ & & $25 \%(16-40)$ & \\
\hline \multirow[t]{2}{*}{ HLA-C } & mismatch & $11 \%(3-41)$ & NS & $0 \%$ & NS & $25 \%(11-58)$ & NS \\
\hline & match & $25 \%(16-49)$ & & $7 \%(3-18)$ & & $31 \%(20-47)$ & \\
\hline \multirow[t]{2}{*}{ HLA-DQB1 } & mismatch & $17 \%(6-49)$ & NS & $6 \%(1-37)$ & NS & $28 \%(13-58)$ & NS \\
\hline & match & $24 \%(15-38)$ & & $5 \%(2-16)$ & & $30 \%(19-46)$ & \\
\hline
\end{tabular}


Table 2. Cont.

\begin{tabular}{|c|c|c|c|c|c|c|c|}
\hline \multicolumn{8}{|c|}{ (b) } \\
\hline & & $\begin{array}{c}3-y \text { OS } \\
(95 \% \text { CI) }\end{array}$ & $p$ & $\begin{array}{l}\text { 3-y TRM } \\
(95 \% \text { CI) }\end{array}$ & $p$ & $\begin{array}{c}\text { 3-y RI } \\
(95 \% \text { CI) }\end{array}$ & $p$ \\
\hline \multirow[t]{2}{*}{$\begin{array}{l}\text { Patient's } \\
\text { gender }\end{array}$} & M & $52 \%(33-70)$ & NS & $20 \%(12-35)$ & NS & $26 \%(17-42)$ & NS \\
\hline & $\mathrm{F}$ & $58 \%(35-91)$ & & $24 \%(12-46)$ & & $14 \%(5-34)$ & \\
\hline \multirow[t]{2}{*}{ Patient's age } & $>60$ year & $27 \%(4-50)$ & 0.005 & $40 \%(25-64)$ & 0.0021 & $20 \%(9-44)$ & NS \\
\hline & $<60$ year & $67 \%(52-83)$ & & $13 \%(7-26)$ & & $23 \%(14-37)$ & \\
\hline \multirow[t]{2}{*}{ Donor } & M & $55 \%(37-74)$ & NS & $21 \%(12-36)$ & NS & $23 \%(14-38)$ & NS \\
\hline & $\mathrm{F}$ & $51 \%(29-74)$ & & $24 \%(13-46)$ & & $21 \%(10-42)$ & \\
\hline \multirow[t]{2}{*}{$\begin{array}{c}\text { GvHD } \\
\text { prophylaxis }\end{array}$} & ATG-based & $42 \%(25-60)$ & 0.005 & $36 \%(24-55)$ & 0.0033 & $15 \%(7-32)$ & NS \\
\hline & PTCy-based & $64 \%(41-88)$ & & $8 \%(2-23)$ & & $28 \%(17-46)$ & \\
\hline \multirow[t]{2}{*}{ Donor's age } & $>30$ & $62 \%(41-83)$ & 0.11 & $17 \%(8-35)$ & NS & $28 \%(17-48)$ & NS \\
\hline & $<30$ & $44 \%(24-65)$ & & $26 \%(15-42)$ & & $16 \%(8-32)$ & \\
\hline \multirow[t]{2}{*}{$\begin{array}{l}\text { Gender } \\
\text { relation }\end{array}$} & $\mathrm{F}>\mathrm{M}$ & $47 \%$ (26-77) & NS & $28 \%(16-49)$ & NS & $25 \%(14-45)$ & NS \\
\hline & other & $57 \%(36-77)$ & & $17 \%(9-33)$ & & $19 \%(11-35)$ & \\
\hline \multirow[t]{2}{*}{ Conditioning } & TBI & $51 \%(19-83)$ & NS & $9 \%(1-59)$ & 0.33 & $36 \%(17-79)$ & NS \\
\hline & Chemo & $55 \%(38-71)$ & & $24 \%(15-37)$ & & $19 \%(12-32)$ & \\
\hline \multirow[t]{2}{*}{$\begin{array}{l}\text { Intensity of } \\
\text { conditioning }\end{array}$} & RIC & $64 \%(30-98)$ & NS & $20 \%()$ & NS & $0 \%$ & 0.06 \\
\hline & MAC & $52 \%(36-68)$ & & & & $39 \%(24-56)$ & \\
\hline \multirow[t]{3}{*}{ DRI } & low & $92 \%(76-100)$ & 0.01 & $8 \%(1-54)$ & 0.21 & $8 \%(1-54)$ & 0.015 \\
\hline & intermediate & $56 \%(36-76)$ & & $21 \%(12-38)$ & & $17 \%(8-33)$ & \\
\hline & high & $26 \%(0-53)$ & & $29 \%(16-54)$ & & $37 \%(22-63)$ & \\
\hline \multirow[t]{6}{*}{ EBMT score } & 2 & $100 \%$ & 0.02 & $0 \%$ & & $0 \%$ & $<0.00001$ \\
\hline & 3 & $68 \%(32-100)$ & & $7 \%(1-47)$ & & $14 \%(4-51)$ & \\
\hline & 4 & $71 \%(49-93)$ & & $10 \%(3-37)$ & & $20 \%(8-48)$ & \\
\hline & 5 & $46 \%(26-67)$ & & $43 \%(27-69)$ & & $26 \%(13-52)$ & \\
\hline & 6 & $49 \%(16-81)$ & & $23 \%(10-55)$ & & $23 \%(10-55)$ & \\
\hline & 7 & $100 \%$ & & $0 \%$ & & $0 \%$ & \\
\hline \multirow[t]{2}{*}{ HLA-A } & mismatch & $59 \%(41-79)$ & NS & $22 \%(12-40)$ & NS & $20 \%(11-37)$ & NS \\
\hline & match & $64 \%(47-81)$ & & $21 \%(11-39)$ & & $21 \%(11-39)$ & \\
\hline \multirow[t]{2}{*}{ HLA-B } & mismatch & $60 \%(33-87)$ & NS & $21 \%(8-58)$ & NS & $14 \%(4-51)$ & NS \\
\hline & match & $60 \%(46-75)$ & & $22 \%(14-35)$ & & $22 \%(14-35)$ & \\
\hline \multirow[t]{2}{*}{ HLA-C } & mismatch & $37 \%$ (13-61) & NS & $28 \%(14-56)$ & NS & $28 \%(14-56)$ & NS \\
\hline & match & $66 \%(52-80)$ & & 19\% (11-33) & & $17 \%(10-31)$ & \\
\hline \multirow[t]{2}{*}{ HLA-DQB1 } & mismatch & $88 \%(73-100)$ & 0.02 & $6 \%(1-37)$ & 0.04 & $17 \%(6-47)$ & NS \\
\hline & match & $54 \%(39-68)$ & & $27 \%(17-40)$ & & $23 \%(15-37)$ & \\
\hline
\end{tabular}


Table 3. Multivariate analysis of factors significantly associated with HSCT outcome. OS = overall survival, $\mathrm{TRM}=$ transplant-related mortality, $\mathrm{OR}=$ odds ratio, $\mathrm{RR}=$ relative risk, $\mathrm{ATG}=$ anti-thymocyte globulin, PT-Cy = post-transplant cyclophosphamide, DRI = disease risk index, $\mathrm{MAC}=$ myeloablative conditioning, RIC = reduced intensity conditioning, $\mathrm{MM}=$ mismatch. The lines in the boxes indicated an absent result. PT-Cy prophylaxis showed a significant value for the GvHD II-IV group in patients more than 60 years old. The RIC conditioning also influenced the GvHD II-IV. The 3-y cGvHD was influenced by PT-Cy and by double MM class 1 and DQB1. The 3-y OS and TRM were influenced by PT-Cy, the patient's age and also by a high DRI.

\begin{tabular}{|c|c|c|c|c|c|c|c|c|c|}
\hline & & $\begin{array}{c}\text { GvHD II-IV } \\
(95 \% \text { CI })\end{array}$ & & $\begin{array}{c}\text { 3-y cGvHD } \\
(95 \% \mathrm{CI})\end{array}$ & & $\begin{array}{c}3-y \text { OS } \\
(95 \% \text { CI })\end{array}$ & & $\begin{array}{l}3-y \text { TRM } \\
(95 \% \text { CI) }\end{array}$ & \\
\hline & Risk factor & OR & $p$ & OR & $p$ & $\mathrm{RR}$ & $p$ & OR & $p$ \\
\hline \multirow{2}{*}{$\begin{array}{c}\text { GvHD } \\
\text { prophylaxis }\end{array}$} & ATG & $\begin{array}{c}1.28 \\
(1.1-3.9)\end{array}$ & \multirow{2}{*}{0.05} & 1 & \multirow{2}{*}{0.001} & 1 & \multirow{2}{*}{0.025} & 1 & \multirow{2}{*}{0.031} \\
\hline & PT-Cy & 1 & & $\begin{array}{c}0.143 \\
(0.07-0.4)\end{array}$ & & $\begin{array}{c}0.342 \\
(0.18-0.56) \\
\end{array}$ & & $\begin{array}{c}0.231 \\
(0.09-0.4)\end{array}$ & \\
\hline \multirow{2}{*}{ Patient's age } & $<60$ year & $\begin{array}{c}0.210 \\
(0.09-0.6)\end{array}$ & \multirow{2}{*}{0.028} & \multirow{2}{*}{ - } & \multirow{2}{*}{ NS } & 1 & \multirow{2}{*}{0.002} & 1 & \multirow{2}{*}{0.01} \\
\hline & $>60$ year & 1 & & & & $3.5(1.9-7.6)$ & & $\begin{array}{c}4.24 \\
(3.6-6.3)\end{array}$ & \\
\hline \multirow{2}{*}{ DRI } & $\begin{array}{c}\text { low- } \\
\text { intermediate }\end{array}$ & \multirow{2}{*}{ 一 } & \multirow{2}{*}{ NS } & \multirow{2}{*}{ - } & \multirow{2}{*}{ NS } & 1 & \multirow{2}{*}{0.005} & 1 & \multirow{2}{*}{0.05} \\
\hline & high & & & & & $2.90(1.2-4.9)$ & & $\begin{array}{c}2.552 \\
(1.9-5.1)\end{array}$ & \\
\hline \multirow[b]{2}{*}{$\begin{array}{c}\text { DQB1 } \\
\text { mismatch }\end{array}$} & no & \multirow[b]{2}{*}{ - } & \multirow[b]{2}{*}{ NS } & \multirow[b]{2}{*}{ - } & \multirow[b]{2}{*}{ NS } & \multirow[b]{2}{*}{ - } & \multirow[b]{2}{*}{ NS } & 1 & \multirow[b]{2}{*}{0.037} \\
\hline & yes & & & & & & & $\begin{array}{c}0.112 \\
(0.08-0.5)\end{array}$ & \\
\hline \multirow[b]{2}{*}{$\begin{array}{l}\text { Intensity of } \\
\text { conditioning }\end{array}$} & MAC & 1 & \multirow[b]{2}{*}{0.008} & \multirow[b]{2}{*}{ - } & \multirow[b]{2}{*}{ NS } & \multirow[b]{2}{*}{ - } & \multirow[b]{2}{*}{ NS } & \multirow[b]{2}{*}{ - } & \multirow[b]{2}{*}{ NS } \\
\hline & RIC & $\begin{array}{c}6.404 \\
(3.4-10.8)\end{array}$ & & & & & & & \\
\hline \multirow{2}{*}{$\begin{array}{l}\text { HLA-class } 1 \\
\text { and DQB1 } \\
\text { mismatches }\end{array}$} & no & \multirow[b]{2}{*}{ - } & \multirow[b]{2}{*}{ NS } & 1 & & & & & \\
\hline & yes & & & $\begin{array}{c}4.170 \\
(2.9-8.6)\end{array}$ & 0.012 & 一 & NS & - & NS \\
\hline
\end{tabular}

The univariate analysis for GvHD III-IV showed that the following factors were significantly associated with a higher risk of severe GvHD: donor age below 30 years $(p=0.054)$, and GvHD prophylaxis with ATG $(p=0.01)$ together the HLA-B mismatch $(p=0.05)$. No factors were identified as independent in the multivariate analysis (Table 3 ).

\subsection{Chronic GvHD Incidence}

Among the entire population the three-year cGvHD incidence was 28\% (95\% CI 19-49). As illustrated in Table 2, the univariate analysis showed that males ( $p=0.04)$, GvHD prophylaxis with ATG $(p=0.0005)$ and HLA-B mismatch $(p=0.0003)$ were significantly associated with cGvHD occurrence. In detail: the cumulative incidence of limited cGvHD were $14 \%(5-34)$ vs. $10 \%(4-27)(p=N S)$ for the ATG and PT-Cy groups, respectively. The cumulative incidence of extensive GvHD were 34\% $(21-57)$ and 3\% $(1-18)(p<0.001)$ for the ATG and PT-Cy groups, respectively. Considering the ATG-group a total of 14 patients developed cGvHD. It was mild for three patients $(10 \%)$, moderate for nine patients $(31 \%)$ and finally severe for two patients $(7 \%)$. When we focused on the PT-Cy group a total of five patients developed cGvHD. It was mild for four patients (10\%) and moderate for one patient (3\%) [43]. When we focused on GvHD prophylaxis, the cumulative incidence 
was $48 \%$ (95\% CI 33-70) for the ATG group and 13\% (95\% CI 6-30, $p=0.0005)$ for the PT-Cy group.

The multivariate analysis found how the PT-Cy-based GvHD prophylaxis (OR 0.143, $p=0.001)$ was a protective factor for CGvHD, while the double class I and HLA-DQB1 mismatch (OR 4.170, $p=0.012$ ) was an independent risk factor for cGvHD (Table 3).

\subsection{Overall Survival}

The three-year OS rate for the entire population was 58\% (95\% CI 49-68). Figure 3 shows the OS for the two groups: $42 \%$ vs. $64 \%$ for ATG and PT-Cy $(p<0.0005)$, respectively. As illustrated in Table 2, the univariate analysis showed that a patient's age above 60 $(p=0.005)$, GvHD prophylaxis with ATG $(p=0.005)$, high DRI $(p=0.01)$ and a match at the HLA-DQB1 locus $(p=0.02)$ were significantly associated with poorer OS.

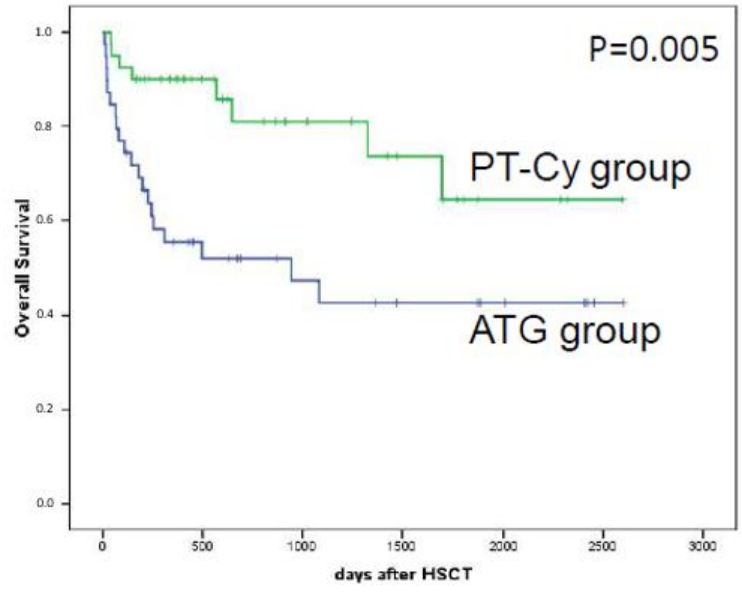

(a)

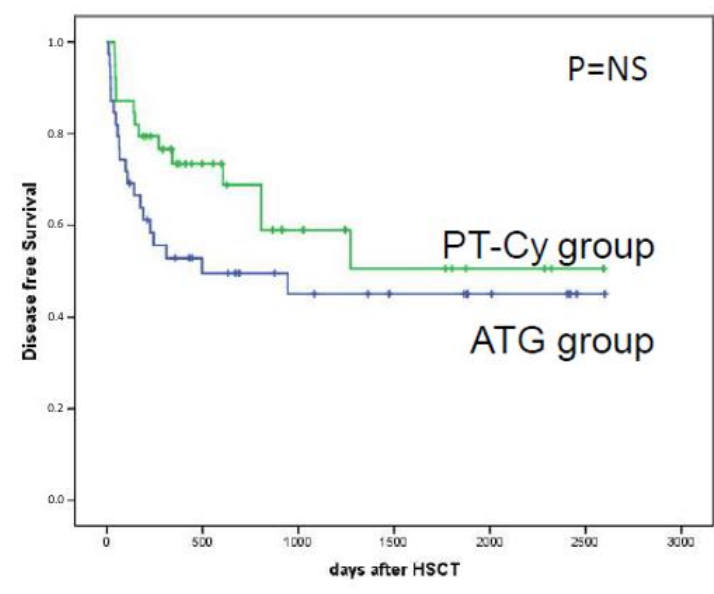

(b)

Figure 3. Comparison of the overall survival and disease-free survival of the patients treated with ATG (blue line) and the patients treated with PT-Cy (green line). In (a), the overall survival after mismatched unrelated donor transplantation underlined a significant result for the PT-Cy group; (b) shows progression-free survival after mismatched unrelated donor transplantation with a nonsignificant $p$ value.

The subsequent multivariate analysis highlights that GvHD prophylaxis with PT-Cy had a protective role (OR 0.342, $p=0.025)$, and older patient's age (OR 3.5, $p=0.002)$ and DRI score (OR 2.90, $p=0.005$ ) were independent risk factors for OS.

When patients were stratified according to DRIs, we found no significant differences for the ATG or PT-Cy groups for low-risk patients, improved OS for PT-Cy patients of intermediate risk ( $41 \%$ vs. $94 \%$, respectively, $p=0.013)$ and an improved outcome for ATG for high risk ( $30 \%$ vs. $25 \%, p=0.04)$.

\subsection{Transplant-Related Mortality}

The three-year transplant-related mortality (TRM) incidence for the entire population was $21 \%(95 \%$, CI $15-29)$. In particular, TRM was $36 \%$ vs. $8 \%(p=0.0033)$ for the ATG and PT-Cy groups, respectively.

As illustrated in Table 2, the univariate analysis showed that statistically, the factors related to TRM risk were: patients' age $(p=0.0021)$, GvHD prophylaxis with ATG $(p=0.0033)$ and a match at the DQB1 locus $(p=0.04)$.

The multivariate analysis found how the PT-Cy based GvHD prophylaxis (OR 0.231, $p=0.031)$ and the mismatch at the HLA-DQB1 locus (OR $0.112, p=0.037$ ) had a protective role, while older patient's age (OR 4.24, $p=0.01)$ and the DRI score (OR 2.552, $p=0.05)$ were independent factors for TRM risk (Table 3). 


\subsection{Relapse Incidence}

Three-year RI for the entire population was 21\% (95\%, CI 15-29), in particular, it was $15 \%$ vs. $28 \%$ ( $p=$ NS) for the ATG and PT-Cy groups, respectively. As reported in Table 2, the univariate analysis showed that the following factors had a statistically significant effect on RI: higher DRI ( $p=0.015)$ and higher EBMT score $(p<0.00001)$.

The multivariate analysis did not find any independent factor.

When patients were stratified according to DRIs we found no significant differences for the ATG or PT-Cy groups for low- and intermediate-risk DRI patients, but a reduced risk of relapse in the ATG group in comparison to PT-Cy (20\% vs. $76 \%, p=$ NS) was observed in high-risk DRI patients.

\subsection{Cause of Death}

Among the ATG-based GvHD prophylaxis patients, 20 died. Seven patients died of septicemia, six due to disease progression, two from refractory GvHD, two from encephalitis, one of myocardial infarction, one due to acute respiratory distress syndrome (ARDS) and one as a result of Alzheimer's disease (histologically proven post mortem).

Among the PT-CY group 10 patients died; 8 of those patients died of disease recurrence and 2 of septicemia.

\section{Discussion and Conclusions}

Mismatched unrelated donor, haploidentical or cord blood HSCTs are considered as alternatives to matched sibling donors or MUD HSCTs. The literature is rich in papers describing the outcomes of alternative donor HSCTs, but comparisons are hard to convert into clinical practice because of different policies for conditioning/GvHD prophylaxis/donor choice/center experience/disease type and phase [44-50]. In this paper we report our comparative study with two strategies of GvHD prophylaxis. The present report is a retrospective observational study and this can explain several limitations; however, there are many points of interest that can be highlighted-in particular, we used the same algorithms for donor search, antifungal and antiviral prophylaxis and the continuous discussion of these clinical cases.

In our study no differences in speed of engraftment were observed among patients having ATG- or PT-Cy-based GvHD prophylaxis; however, the rate of failure of PLT engraftment was significantly greater for the ATG group. The reason is unclear, since the PT-Cy is able to spare stem cells but not committed progenitors, whereas ATG does not affect stem cell behavior. The literature reports approximately a $10 \%$ graft failure rate in MMUD transplants, which is significantly higher than that observed in matched sibling donors and MUD transplants [47]. In our study, the older patient's median age in the ATG group together with the more advanced disease risk may explain these results.

Concerning GvHD occurrence, we observed that the GvHD risk was reduced with the addition of PT-Cy since the acute and chronic GvHD were significantly lower in comparison with the ATG group. However, this is counterbalanced by the higher risk of relapse in our population that, for the adult patients, was nearly double in the PT-Cy group [51]. This limited GvHD incidence distinguished our PT-Cy cohort from other MMUD HSCT cases reported in the literature. In the 2016 Mehta paper, after the exclusion of 29 patients with isolated HLA-DQ mismatches, 84 patients were identified as '7/8 HLAMUD' HCT recipients. Out of these, 38 patients received PTCy-based GvHD prophylaxis while 46 patients received tacrolimus/MTX/ATG or alemtuzumab. No patient in the PT-Cy group developed acute GvHD by day 30 compared with eight patients in the conventional group [52]. In a recent paper by Jorge et al., a more pronounced incidence of acute and chronic GvHD was reported [53]. Battipaglia et al. also registered higher GvHD rates than in our cohort of patients [22]. The use of tacrolimus distinguished our PT-Cy cohort (all 40 patients vs. 19 in the EBMT study) but the data gathered do not allow for any further speculations. In the ATG group the Cy-A was maintained around $150 \mathrm{ng} / \mathrm{mL}$ to reduce 
toxicity; however, this level might be insufficient for inhibiting T-cell alloreactivity in this unrelated mismatched HSCT setting [54].

In a large CIBMTR study, no differential impact of mismatching at HLA-A, -B, -C or -DRB1 was detected for either relapsed or chronic GvHD, but mismatch at HLA-A was significantly associated with grade III-IV aGvHD and TRM together with lower DFS and OS rates [43]. Another large NMDP study, analyzing one single antigen MMUD with $\mathrm{GvH}$ and bidirectional vector, had significantly higher rates of acute GvHD than the 7/8 HvG mismatched group [45]. Here we cannot confirm these data, probably due to the low number of our patients. In our series we were able to find that the HLA-B mismatch was significantly associated with GvHD III-IV (the $p$ value of GvHD II-IV was 0.06) and cGvHD, whereas the HLA-DQB1 mismatch gave protection against TRM and improved OS [49].

Regarding TRM, the different GvHD prophylaxis reached statistical significance with a reduced TRM emerging for the PT-Cy group (only 7\%). Jorge et al. reported $24 \%$ of TRM in an adult population. In their study no differences in the cumulative incidence of TRM at 1 year were observed between PT-Cy MMUD and MUD. We found that the patient's age and ATG-based GvHD prophylaxis had a more significant impact on TRM.

The package of GvHD prevention presented different risks of relapse, which were higher in the PT-Cy group (28\%) compared to the ATG group (15\%); however, the multivariate analysis did not confirm the statistical significance. Nonetheless, RI appears an important cause of treatment failure especially in the PT-Cy group. The advanced DRI and advanced EBMT risk scores were the only factors significantly associated with a higher risk of relapse, which confirmed evidence gathered in previous studies. This observation confirms data from the CIBMTR [43].

In our study the RI increased from $8 \%$ to $37 \%$ according to DRI, and more importantly RI was unaffected by GvHD prophylaxis in the low or intermediate groups. We recorded a greater difference in RI in the high DRI score between ATG (20\%) vs. PT-Cy (76\%). These data need to be confirmed by other groups in a prospective study. A previous paper including 775 patients firstly documented an increased risk for TRM associated with an HLA-mismatch, even in the setting of ATG-based transplants [55]. PTCy may circumvent the issue of NRM associated with an HLA MM, although at the price of a higher relapse rate, as suggested by the present findings.

The limited role of the HLA mismatch donor in preventing relapse was confirmed in other papers. In the study of Arora et al., the five-year cumulative incidence of relapse was $14 \%$ in matched sibling donor transplant recipients, $12 \%$ in $8 / 8$ matched unrelated transplant recipients, $11 \%$ with single class I mismatch, 9\% with single DRB1 mismatch, $7 \%$ with two class I mismatches and $12 \%$ with mixed mismatch [56].

In our study, factors associated with a lower risk of death were low DRI, younger patient's age, PT-Cy GvHD prophylaxis and mismatch at the HLA-DQB1 mismatch. Data on preventing relapse with a MHC-class II mismatch have already been explored by other studies. Solomon's paper describes how patients receiving a haploidentical HSCT with PTCY had improved survival in the presence of HLA-DR mismatch, HLA-DP nonpermissive mismatch, killer cell immunoglobulin-like receptor (KIR) receptor-ligand mismatch, and KIR B/x haplotype with KIR2DS2 [57].

Among these factors, multivariate analysis showed how GvHD prophylaxis with PT-Cy, younger age and lower DRI score were significantly associated with better survival rates. When our patients were stratified according to GvHD prophylaxis and DRI score, no significant differences in the low-risk group were observed, whereas OS was significantly affected by GvHD prophylaxis (better with PT-Cy in the intermediate-risk and slightly better with ATG in the high-risk group). Again, in our opinion these data should be kept in mind when HSCT is offered to new patients.

However, all of these conclusions can be mitigated by the non-homogeneous nature of the group of neoplastic diseases we treated and their different conditioning at the different disease phases at HSCT. We did not find that HLA mismatch influenced OS 
rates, except for the protective role of DQB1 mismatch. In Kekre's paper, the subgroup analyses showed an increased risk of mortality with single allele mismatches at HLA-A, HLA-B and HLA-C when compared with fully matched unrelated donor HSCT, while HLA-DRB1, DQB1 or HLA-DPB1 associations were not significant [51]. With all the limitations of the retrospective analysis, we were able to show how PT-Cy is capable of reducing GvHD incidence and TRM in an adult population. These data confirm that GvHD may be significantly reduced but relapse remains a critical point. The long-lasting immunosuppression given by PT-Cy might be an issue in high-risk diseases. Our data suggest the consideration of ATG for high-risk disease patients and PT-Cy in the case of those patients at low or intermediate risk. Studies addressing a post-HSCT approach to reduce RI are warranted and cellular therapies might represent an intriguing option. Allogeneic CAR-T cells or allogeneic CIK cells after HSCT [58-61] are under investigation worldwide and are worthy of note in this area.

Author Contributions: Conceptualization, M.B. (Massimo Berger) and M.B. (Marta Barone), methodology, M.B. (Massimo Berger), F.C.-S. and M.D.G. software, Massimo Berger; validation, F.C.-S., M.D.G., M.A., F.F.; formal analysis, M.B. (Massimo Berger) and M.B. (Marta Barone), investigation, P.N., D.C. (Daniela Caravelli), D.C. (Daniela Cilloni), L.P.; data curation, M.B. (Massimo Berger), writing-original draft preparation, M.B. (Massimo Berger) and M.B. (Marta Barone); writing—review and editing, K.M., M.S.; supervision, F.F.; project administration, F.F. and M.A. All authors have read and agreed to the published version of the manuscript.

Funding: This research received no external funding.

Institutional Review Board Statement: The study was conducted according to the guidelines of the Declaration of Helsinki, and approved by the Institutional Review Board (or Ethics Committee) of Comitato Etico Città della Salute e della Scienza di Torino n ${ }^{\circ}$ Pratica N. 00266/2019 on 26/06/2020.

Informed Consent Statement: Informed consent was obtained from all subjects involved in the study.

Data Availability Statement: https:/ / we.tl/t-YD6kK1M12P (accessed on 16 November 2021).

Conflicts of Interest: The authors have nothing to disclose.

\section{References}

1. Ballen, K.K.; King, R.J.; Chitphakdithai, P.; Bolan, C.D., Jr.; Agura, E.; Hartzman, R.J.; Kernan, N.A. The national marrow donor program 20 years of unrelated donor hematopoietic cell transplantation. Biol. Blood Marrow Transplant. 2008, 14, 2-7. [CrossRef] [PubMed]

2. Kekre, N.; Antin, J.H. Hematopoietic stem cell transplantation donor sources in the 21st century: Choosing the ideal donor when a perfect match does not exist. Blood 2014, 124, 334-343. [CrossRef]

3. Ciurea, S.O.; Saliba, R.M.; Rondon, G.; Patah, P.A.; Aung, F.; Cano, P.; Andersson, B.S.; Kebriaei, P.; Popat, U.; Fernandez-Vina, M.; et al. Outcomes of patients with myeloid malignancies treated with allogeneic hematopoietic stem cell transplantation from matched unrelated donors compared with one human leukocyte antigen mismatched related donors using HLA typing at 10 loci. Biol. Blood Marrow Transplant. 2011, 17, 923-929. [CrossRef] [PubMed]

4. Nakamae, H.; Storer, B.E.; Storb, R.; Storek, J.; Chauncey, T.R.; Pulsipher, M.A.; Petersen, F.B.; Wade, J.C.; Maris, M.B.; Bruno, B.; et al. Low-dose total body irradiation and fludarabine conditioning for HLA class I-mismatched donor stem cell transplantation and immunologic recovery in patients with hematologic malignancies: A multicenter trial. Biol. Blood Marrow Transplant. 2010, 16, 384-394. [CrossRef]

5. Mehta, J.; Singhal, S.; Gee, A.P.; Chiang, K.Y.; Godder, K.; van Rhee, F.; DeRienzo, S.; O’Neal, W.; Lamb, L.; Henslee-Downey, P.J. Bone marrow transplantation from partially HLA-mismatched family donors for acute leukemia: Single-center experience of 201 patients. Bone Marrow Transplant. 2004, 33, 389-396. [CrossRef]

6. Hauzenberger, D.; Schaffer, M.; Ringdén, O.; Hassan, Z.; Omazic, B.; Mattsson, J.; Wikström, A.-C.; Remberger, M. Outcome of haematopoietic stem cell transplantation in patients transplanted with matched unrelated donors vs allele-mismatched donors: A single centre study. Tissue Antigens 2008, 72, 549-558. [CrossRef] [PubMed]

7. Lee, S.J.; Klein, J.; Haagenson, M.; Baxter-Lowe, L.A.; Confer, D.L.; Eapen, M.; Fernandez-Vina, M.; Flomenberg, N.; Horowitz, M.; Hurley, C.K.; et al. High-resolution donor-recipient HLA matching contributes to the success of unrelated donor marrow transplantation. Blood 2007, 110, 4576-4583. [CrossRef]

8. Woolfrey, A.; Klein, J.P.; Haagenson, M.; Spellman, S.; Petersdorf, E.; Oudshoorn, M.; Gajewski, J.; Hale, G.A.; Horan, J.; Battiwalla, M.; et al. HLA-C antigen mismatch is associated with worse outcome in unrelated donor peripheral blood stem cell transplantation. Biol. Blood Marrow Transplant. 2011, 17, 885-892. [CrossRef] 
9. Ruutu, T.; van Biezen, A.; Hertenstein, B.; Henseler, A.; Garderet, L.; Passweg, J.; Mohty, M.; Sureda, A.; Niederwieser, D.; Gratwohl, A.; et al. Prophylaxis and treatment of GVHD after allogeneic haematopoietic SCT: A survey of centre strategies by the European Group for Blood and Marrow Transplantation. Bone Marrow Transplant. 2012, 47, 1459-1464. [CrossRef]

10. Ruutu, T.; Gratwohl, A.; Niederwieser, D.; de Witte, T.; van der Werf, S.; van Biezen, A.; Mohty, M.; Kröger, N.; Rambaldi, A.; McGrath, E.; et al. The EBMT-ELN working group recommendations on the prophylaxis and treatment of GvHD: A change-control analysis. Bone Marrow Transplant. 2017, 52, 357-362. [CrossRef]

11. Scheinberg, P.; Nunez, O.; Weinstein, B.; Scheinberg, P.; Biancotto, A.; Wu, C.O.; Young, N.S. Horse versus rabbit antithymocyte globulin in acquired aplastic anemia. N. Engl. J. Med. 2011, 365, 430-438. [CrossRef]

12. Kekre, N.; Zhang, Y.; Zhang, M.J.; Carreras, J.; Ahmed, P.; Anderlini, P.; Atta, E.H.; Ayas, M.; Boelens, J.J.; Bonfim, C.; et al. Effect of antithymocyte globulin source on outcomes of bone marrow transplantation for severe aplastic anemia. Haematologica 2017, 102, 1291-1298. [CrossRef] [PubMed]

13. Chen, X.; Wei, J.; Huang, Y.; He, Y.; Yang, D.; Zhang, R.; Jiang, E.; Ma, Q.; Zhai, W.; Yao, J.; et al. Effect of antithymocyte globulin source on outcomes of HLA-matched sibling allogeneic hematopoietic stem cell transplantation for patients with severe aplastic anemia. Biol. Blood Marrow Transplant. 2018, 24, 86-90. [CrossRef]

14. Kröger, N.; Solano, C.; Wolschke, C.; Bandini, G.; Patriarca, F.; Pini, M.; Nagler, A.; Selleri, C.; Risitano, A.; Messina, G.; et al Antilymphocyte Globulin for Prevention of Chronic Graft-versus-Host Disease. N. Engl. J. Med. 2016, 374, 43-53. [CrossRef]

15. Kanakry, C.G.; O’Donnell, P.V.; Furlong, T.; De Lima, M.J.; Wei, W.; Medeot, M.; Mielcarek, M.; Champlin, R.E.; Jones, R.J.; Thall, P.F.; et al. Multi-institutional study of post-transplantation cyclophosphamide as single-agent graft-versus-host disease prophylaxis after allogeneic bone marrow transplantation using myeloablative busulfan and fludarabine conditioning. J. Clin. Oncol. 2014, 32, 3497-3505. [CrossRef] [PubMed]

16. Kanakry, C.G.; Fuchs, E.J.; Luznik, L. Modern approaches to HLA-haploidentical blood or marrow transplantation. Nat. Rev. Clin. Oncol. 2016, 13, 10-24. [CrossRef] [PubMed]

17. Kanakry, C.G.; Ganguly, S.; Zahurak, M.; Bolaños-Meade, J.; Thoburn, C.; Perkins, B.; Fuchs, E.J.; Jones, R.J.; Hess, A.D.; Luznik, L. Aldehyde dehydrogenase expression drives human regulatory T cell resistance to post-transplantation cyclophosphamide. Sci. Transl. Med. 2013, 5, 211ra157. [CrossRef]

18. Carnevale-Schianca, F.; Caravelli, D.; Gallo, S.; Coha, V.; D’Ambrosio, L.; Vassallo, E.; Fizzotti, M.; Nesi, F.; Gioeni, L.; Berger M.; et al. Post-Transplant Cyclophosphamide and Tacrolimus-Mycophenolate Mofetil Combination Prevents Graft-versus-Host Disease in Allogeneic Peripheral Blood Hematopoietic Cell Transplantation from HLA-Matched Donors. Biol. Blood Marrow Transplant. 2017, 23, 459-466. [CrossRef]

19. Al-Homsi, A.S.; Roy, T.S.; Cole, K.; Feng, Y.; Duffner, U. Post-transplant high-dose cyclophosphamide for the prevention of graft-versus-host disease. Biol. Blood Marrow Transplant. 2015, 21, 604-611. [CrossRef]

20. Berger, M.; Lanino, E.; Cesaro, S.; Zecca, M.; Vassallo, E.; Faraci, M.; De Bortoli, M.; Barat, V.; Prete, A.; Fagioli, F. Feasibility and Outcome of Haploidentical Hematopoietic Stem Cell Transplantation with Post-Transplant High-Dose Cyclophosphamide for Children and Adolescents with Hematologic Malignancies: An AIEOP-GITMO Retrospective Multicenter Study. Biol. Blood Marrow Transplant. 2016, 22, 902-909. [CrossRef]

21. Saglio, F.; Berger, M.; Spadea, M.; Pessolano, R.; Carraro, F.; Barone, M.; Quarello, P.; Vassallo, E.; Fagioli, F. Haploidentical HSCT with post transplantation cyclophosphamide versus unrelated donor HSCT in pediatric patients affected by acute leukemia. Bone Marrow Transplant. 2020, 56, 586-595. [CrossRef] [PubMed]

22. Battipaglia, G.; Labopin, M.; Kröger, N.; Vitek, A.; Afanasyev, B.; Hilgendorf, I.; Schetelig, J.; Ganser, A.; Blaise, D.; Itälä-Remes, M.; et al. Posttransplant cyclophosphamide vs antithymocyte globulin in HLA-mismatched unrelated donor transplantation. Blood 2019, 134, 892-899. [CrossRef] [PubMed]

23. Nagler, A.; Kanate, A.S.; Labopin, M.; Ciceri, F.; Angelucci, E.; Koc, Y.; Gülbas, Z.; Arcese, W.; Tischer, J.; Pioltelli, P.; et al. Post-transplant cyclophosphamide versus antithymocyte globulin for graft-versus-host disease prevention in haploidentical transplantation for adult acute lymphoblastic leukemia. Haematologica 2021, 106, 1591. [CrossRef] [PubMed]

24. Shaw, B.E.; Jimenez-Jimenez, A.M.; Burns, L.J.; Logan, B.R.; Khimani, F.; Shaffer, B.C.; Shah, N.N.; Mussetter, A.; Tang, X.-Y.; McCarty, J.M.; et al. National Marrow Donor Program-Sponsored Multicenter, Phase II Trial of HLA-Mismatched Unrelated Donor Bone Marrow Transplantation Using Post-Transplant Cyclophosphamide. J. Clin. Oncol. 2021, 39, 1971-1982. [CrossRef]

25. Bailén, R.; Kwon, M.; Pascual-Cascón, M.J.; Ferrà, C.; Sanz, J.; Gallardo-Morillo, A.; García-Sola, A.; Torrent, A.; Jiménez-Lorenzo, M.J.; Piñana, J.L.; et al. Post-transplant cyclophosphamide for GVHD prophylaxis compared to ATG-based prophylaxis in unrelated donor transplantation. Ann. Hematol. 2021, 100, 541-553. [CrossRef]

26. Gao, F.; Zhang, J.; Hu, J.; Lin, L.; Xu, Y. Post-transplant cyclophosphamide versus antithymocyte globulin in allogeneic hematopoietic cell transplantation: A meta-analysis. Ann. Hematol. 2021, 100, 529-540. [CrossRef] [PubMed]

27. Fujiwara, S.; Hattori, N.; Matsui, T.; Nakata, A.; Sasaki, Y.; Shimada, S.; Murai, S.; Abe, M.; Baba, Y.; Watanuki, M.; et al. Refined Disease Risk Index for Hematological Malignancies, Including Rare Disorders, After Allogeneic Stem Cell Transplantation. Transplant. Proc. 2019, 51, 3437-3443. [CrossRef]

28. Armand, P.; Gibson, C.J.; Cutler, C.; Ho, V.T.; Koreth, J.; Alyea, E.P.; Ritz, J.; Sorror, M.L.; Lee, S.J.; Deeg, H.J.; et al. A disease risk index for patients undergoing allogeneic stem cell transplantation. Blood 2012, 120, 905-913. [CrossRef]

29. Gratwohl, A. The EBMT risk score. Bone Marrow Transplant. 2012, 47, 749-756. [CrossRef] 
30. Tiercy, J.M. How to select the best available related or unrelated donor of hematopoietic stem cells? Haematologica 2016, 101, 680-687. [CrossRef]

31. Fürst, D.; Neuchel, C.; Tsamadou, C.; Schrezenmeier, H.; Mytilineos, J. HLA Matching in Unrelated Stem Cell Transplantation up to Date. Transfus. Med. Hemother. 2019, 46, 326-336. [CrossRef] [PubMed]

32. Fleischhauer, K. Selection of matched unrelated donors moving forward: From HLA allele counting to functional matching. Hematol. Am. Soc. Hematol. Educ. Program. 2019, 2019, 532-538. [CrossRef] [PubMed]

33. Oran, B.; Saliba, R.M.; Carmazzi, Y.; de Lima, M.; Rondon, G.; Ahmed, S.; Alousi, A.; Andersson, B.S.; Anderlini, P.; Alvarez, M.; et al. Effect of nonpermissive HLA-DPB1 mismatches after unrelated allogeneic transplantation with in vivo T-cell depletion. Blood 2018, 131, 1248-1257. [CrossRef] [PubMed]

34. Pidala, J.; Wang, T.; Haagenson, M.; Spellman, S.R.; Askar, M.; Battiwalla, M.; Baxter-Lowe, L.A.; Bitan, M.; Fernandez-Viña, M.; Gandhi, M.; et al. Amino acid substitution at peptide-binding pockets of HLA class I molecules increases risk of severe acute GVHD and mortality. Blood 2013, 122, 3651-3658. [CrossRef]

35. Glucksberg, H.; Storb, R.; Fefer, A.; Buckner, C.D.; Neiman, P.E.; Clift, R.A.; Lerner, K.G.; Thomas, E.D. Clinical manifestations of graft-versus-host disease in human recipients of marrow from HL-A-matched sibling donors. Transplantation 1974, 18, $295-304$. [CrossRef]

36. Shulman, H.M.; Sullivan, K.M.; Weiden, P.L.; McDonald, G.B.; Striker, G.E.; Sale, G.E.; Sale, G.E.; Hackman, R.; Tsoi, M.-S.; Storb, R.; et al. Chronic graft-versus-host syndrome in man. A long-term clinicopathologic study of 20 Seattle patients. Am. J. Med. 1980, 69, 204-217. [CrossRef]

37. Spyridonidis, A.; Labopin, M.; Savani, B.N.; Niittyvuopio, R.; Blaise, D.; Craddock, C.; Socié, G.; Platzbecker, U.; Beelen, D.; Milpied, N.; et al. Redefining and measuring transplant conditioning intensity in current era: A study in acute myeloid leukemia patients. Bone Marrow Transplant. 2020, 55, 1114-1125. [CrossRef]

38. Conover, W.J. Practical Nonparametric Statistics, 2nd ed.; Wiley: New York, NY, USA, 1980; p. 493.

39. Walpole, R.E.; Myers, R.H.; Myers, S.L.; Ye, K.E. Probability and Statistics for Engineers and Scientists, 9th ed.; Pearson: London, UK, 2012.

40. Kaplan, E.L.; Meier, P. Nonparametric estimation from incomplete observations. J. Am. Stat. Assoc. 1958, 53, 457-481. [CrossRef]

41. Bland, J.M.; Altman, D.G. The logrank test. BMJ 2004, 328, 1073. [CrossRef]

42. Kim, H.T. Cumulative incidence in competing risks data and competing risks regression analysis. Clin. Cancer Res. 2007, 13 Pt 1 , 559-565. [CrossRef] [PubMed]

43. Verneris, M.R.; Lee, S.J.; Ahn, K.W.; Wang, H.L.; Battiwalla, M.; Inamoto, Y.; Fernandez-Vina, M.A.; Gajewski, J.; Pidala, J.; Munker R.; et al. HLA-mismatch is associated with worse outcomes after unrelated donor reduced intensity conditioning hematopoietic cell transplantation: An analysis from the CIBMTR. Biol. Blood Marrow Transplant. 2015, 21, 1783-1789. [CrossRef] [PubMed]

44. Jagasia, M.H.; Greinix, H.T.; Arora, M.; Williams, K.M.; Wolff, D.; Cowen, E.W.; Palmer, J.; Weisdorf, D.; Treister, N.S.; Cheng, G.-S.; et al. National Institutes of Health Consensus Development Project on Criteria for Clinical Trials in Chronic Graft-versus-Host Disease: I. The 2014 Diagnosis and Staging Working Group report. Biol. Blood Marrow Transplant. 2015, 21, 389-401.e1. [CrossRef] [PubMed]

45. Katovich Hurley, C.; Woolfrey, A.; Wang, T.; Haagenson, M.; Umejiego, J.; Aljurf, M.; Battiwalla, M.; Dehn, J.; Horan, J.; Oudshoorn, M.; et al. The impact of HLA unidirectional mismatches on the outcome of myeloablative hematopoietic stem cell transplantation with unrelated donors. Blood 2013, 121, 4800-4806. [CrossRef] [PubMed]

46. Gaballa, S.; Ge, I.; El Fakih, R.; Brammer, J.E.; Kongtim, P.; Tomuleasa, C.; Wang, S.A.; Lee, D.; Petropoulos, D.; Cao, K.; et al Results of 2-arm, phase 2 clinical trial using post-transplantation Cyclophopshamide for the prevention of graft-versus-host disease in haploidentical donor and mismatched unrelated donor hematopoietic stem cell transplantation. Cancer 2016, 123, 3316-3326. [CrossRef]

47. Crocchiolo, R.; Ciceri, F.; Fleischhauer, K.; Oneto, R.; Bruno, B.; Pollichieni, S.; Sacchi, N.; Sormani, M.P.; Fanin, R.; Bandini, G.; et al. HLA matching affects clinical outcome of adult patients undergoing haematopoietic SCT from unrelated donors: A study from the Gruppo Italiano Trapianto di Midollo Osseo and Italian Bone Marrow Donor Registry. Bone Marrow Transplant. 2009, 44, 571-577. [CrossRef] [PubMed]

48. Hasegawa, W.; Lipton, J.H.; Messner, H.A.; Jamal, H.; Yi, Q.L.; Daly, A.S.; Kotchetkova, N.; Kiss, T.L. Influence of one human leukocyte antigen mismatch on outcome of allogeneic bone marrow transplantation from related donors. Hematology 2003, 8, 27-33. [CrossRef]

49. Kekre, N.; Mak, K.S.; Stopsack, K.H.; Binder, M.; Ishii, K.; Brånvall, E.; Cutler, C.S. Impact of HLA-Mismatch in Unrelated Donor Hematopoietic Stem Cell Transplantation: A Meta-Analysis. Am. J. Hematol. 2016, 91, 551-555. [CrossRef]

50. Modi, D.; Kondrat, K.; Kim, S.; Deol, A.; Ayash, L.; Ratanatharathorn, V.; Uberti, J.P. Post-transplant Cyclophosphamide Versus Thymoglobulin in HLA-Mismatched Unrelated Donor Transplant for Acute Myelogenous Leukemia and Myelodysplastic Syndrome. Transplant. Cell. Ther. 2021, 27, 760-767. [CrossRef]

51. Luznik, L.; O’Donnell, P.V.; Symons, H.J.; Chen, A.R.; Leffell, M.S.; Zahurak, M.; Gooley, T.A.; Piantadosi, S.; Kaup, M.; Ambinder R.F.; et al. HLA-haploidentical bone marrow transplantation for hematological malignancies using nomyeloablative conditioning and high-dose post transplantation Cyclophosphamide. Biol. Blood Marrow Transplant. 2008, 14, 641-650. [CrossRef] 
52. Mehta, R.S.; Saliba, R.M.; Chen, J.; Rondon, G.; Hammerstrom, A.E.; Alousi, A.; Qazilbash, M.; Bashir, Q.; Ahmed, S.; Popat, U.; et al. Post-transplantation cyclophosphamide versus conventional graft-versus-host disease prophylaxis in mismatched unrelated donor haematopoietic cell transplantation. Br. J. Haematol. 2016, 173, 444-455. [CrossRef]

53. Jorge, A.S.; Lledo, M.S.; Pereira, A.; Gutierrez, G.; Fernández-Avilés, F.; Rosiñol, L.; Llobet, N.; Solano, T.; Urbano-Ispízua, A.; Rovira, M.; et al. Single antigen-mismatched unrelated hematopoietic stem cell transplantation using high-dose posttransplantation cyclophosphamide is a suitable alternative for patients lacking HLA-matched donors. Biol. Blood Marrow Transplant. 2018, 24, 1196-1202. [CrossRef]

54. Arora, M.; Weisdorf, D.J.; Spellman, S.; Haagenson, M.D.; Klein, J.P.; Hurley, C.K.; Selby, G.B.; Antin, J.H.; Kernan, N.A.; Kollman, C.; et al. HLA-identical sibling compared with $8 / 8$ matched and mismatched unrelated donor bone marrow transplant for chronic phase chronic myeloid leukemia. J. Clin. Oncol. 2009, 27, 1644-1652. [CrossRef]

55. Ruutu, T.; Gratwohl, A.; de Witte, T.; Afanasyev, B.; Apperley, J.; Bacigalupo, A.; Dazzi, F.; Dreger, P.; Duarte, R.; Finke, J.; et al. Prophylaxis and treatment of GVHD: EBMT-ELN working group recommendations for a standardized practice. Bone Marrow Transplant. 2014, 49, 168-173. [CrossRef]

56. Clausen, J.; Böhm, A.; Straßl, I. HLA-C KIR-Ligands Determine the Impact of Anti-Thymocyte Globulin (ATG) on Graft versus Host and Graft versus Leukemia Effects Following Hematopoietic Stem Cell Transplantation. Biomedicines 2017, 5, 13. [CrossRef] [PubMed]

57. Schlegel, P.; Lang, A.M.; Matela, M.; Horrer, A.; Schilling, A.; Joechner, A.; Wiedenmann, M.; Seitz, C.; Döring, M.; Feuchtinger, T.; et al. Ex vivo expansion of autologous, donor-derived NK-, $\gamma \delta \mathrm{T}-$, and cytokine induced killer (CIK) cells post haploidentical hematopoietic stem cell transplantation results in increased antitumor activity. Bone Marrow Transplant. 2019, 54, 727-732. [CrossRef] [PubMed]

58. Solomon Scott, R.; Aubrey Michael, T.; Zhang, X. Selecting the Best Donor for Haploidentical Transplant: Impact of HLA, Killer Cell Immunoglobulin-Like Receptor Genotyping, and Other Clinical Variables. Biol. Blood Marrow Transplant. 2018, 24, 789-798. [CrossRef] [PubMed]

59. Narayan, R.; Benjamin, J.E.; Shah, O.; Tian, L.; Tate, K.; Armstrong, R.; Xie, B.J.; Lowsky, R.; Laport, G.; Negrin, R.S.; et al. Donor-Derived Cytokine-Induced Killer Cell Infusion as Consolidation after Nonmyeloablative Allogeneic Transplantation for Myeloid Neoplasms. Biol. Blood Marrow Transplant. 2019, 25, 1293-1303. [CrossRef]

60. Zhang, C.; Ma, Y.Y.; Liu, J.; Liu, Y.; Gao, L.; Gao, L.; Kong, P.-Y.; Xiong, Q.-H.; Mei, W.-L.; Liu, J.; et al. Preventive infusion of donor-derived CAR-T cells after haploidentical transplantation: Two cases report. Medicine 2019, 98, e16498. [CrossRef] [PubMed]

61. Ayuk, F.; Fehse, B.; Janson, D.; Berger, C.; Riecken, K.; Kröger, N. Excellent proliferation and persistence of allogeneic donorderived 41-BB based CAR-T cells despite immunosuppression with cyclosporine A. Haematologica 2020, 105, 322-324. [CrossRef] 